\title{
Optimizing the Management Control System for Responsibility Centers
}

Accurately defining what type of responsibility center (RC) a department will be is vital for a company's management control system to work effectively. Budgeting, appraisal, accounting, and incentivization all revolve around RCs. The purpose of defining RCs is to properly assign responsibilities, streamline management, and motivate the workforce. How do we define an RC? This is one of the major questions that a management control system must answer. Key considerations include the nature of the business and the type of operating mechanism. All in all, the operating mechanism must be value-driven.

RCs usually correlate to accounting granularity, or what order of magnitude their accounting deals with. Huawei's practices prove that granularity should be small and determined by actual circumstances. Otherwise, it will be difficult to properly assign business management responsibilities and determine how much value a team brings to the company. The inability to determine this value will make it difficult to tie incentives to contributions, causing organizational vitality to suffer. But this does not mean that smaller granularity is always better, because overly small granularity leads to more internal transaction interfaces and higher internal transaction costs. Therefore, a key consideration of management control is to define RCs from a strategic perspective to ensure cost effectiveness.

Huawei's experience has proven that a system of checks and balances must be in place between RCs. Profit centers, such as product lines and representative offices, must have their unique areas of focus. A product 
line - as a profit center - should prioritize revenue over profits, and maximize revenue with a more aggressive sales plan. A representative office, which is also a type of profit center, should focus on profits over revenue, so its sales plan tends to be more conservative. This arrangement enables us to strike a balance between being aggressive and being conservative, with checks and balances in place.

RC appraisal and incentive mechanisms must be designed in a way that ties incentives to results and encourages collective dedication. These mechanisms need to widen the gaps between incentives for different teams based on their results, or contributions. The mechanisms must also reinforce the company's customer-centric culture and fine tradition of "toasting those who succeed and offering a helping hand to those who fail". Huawei achieves these goals with multiple methods, including adjusted statistics and adjusted performance appraisals.

HQ must serve as a resource pool, and resources must be bought and sold according to market rules. Building HQ as a resource pool and field offices as profit centers is the direction in which Huawei is heading. Budgets for HQ are set at a baseline that is adequate to help maintain its normal operations. If HQ wants more money, it needs to provide resources and services to field offices and charge them for these resources and services. Field profit centers must bear the costs for these resources and services. This is the resource "buy \& sell" model. It puts checks and balances between field and back offices to ensure that field offices don't become aimless and back offices have clearly defined capability requirements.

This chapter discusses in detail the above key points of management control systems for RCs.

\subsection{Every Operating Mechanism Is Ultimately VALUE-DRIVEN}

\subsubsection{Making Accounting Granularity Small as Needed}

We need to transform field offices and product lines from revenue centers into profit centers. We have spent two decades of effort building up our organization and market presence. We did not do this just to bleed our capital or end up getting nowhere. The transformation of field offices into profit centers must gradually begin. When the marketing and sales team in China reported their work, they talked about how many contributions they had made and how great they were. But I just want to ask, "What 
contributions have you made to the company? Have you contributed enough profits to the company?" After being developed for 18 years, the Chinese market has matured. Currently, the marketing and sales team in China should earn enough profits for the company to support market development and product lines. This is how we should transform field offices into profit centers. (Ren Zhengfei: Adapting the Manager Appraisal System to Challenges Facing the Transforming Industry, Huawei Executive Office Speech No. [2006] 036)

Non-core business departments need to gradually shift towards independent accounting. They need to find their own way to make profits and survive, to use a market-driven approach to transact with core business departments. Smartcom (Huawei's subsidiary) and Staff Plaza (an arm of Smartcom) have both successfully rolled out independent accounting. Huawei University needs to do the same. You can scale up your business when profits grow, or scale it down if products and services are not selling well. (Ren Zhengfei: Minutes of the Second Report on the 2012 Corporate Budget, EMT Meeting Minutes No. [2012] 010)

We need to meaningfully restructure our organization to increase efficiency and reduce redundant workforce. Can field offices work normally if an entire HQ team takes a month of leave all together? If the answer is yes, then that HQ team is unnecessary. HQ must be downsized; otherwise, salary raises won't be allowed. If the downsizing of an HQ team negatively impacts the business of field offices, we need to figure out who really need to carry out their business. If field offices don't experience any pains after the downsizing, then that HQ team is simply redundant. If the team has no effect on field offices, it needs to be disbanded. It's like if you have a multi-horse wagon and the reins for one of the horses are always loose. This means the horse isn't running fast enough and is thus not necessary. It's better to cut these reins and let the horse go. Our organizational restructuring should follow the same approach. (Ren Zhengfei: Speech at the EMT ST Meeting, 2012)

A representative office's level depends on how much value it creates for the company, rather than the size of the country it represents. Every project must generate profits. Our best resources must be channeled to valued customers. We must first decide how many resources we invest in a customer based on the profit margin they can offer us, and then we work to improve customer satisfaction. We define "big project" as any project that earns us big money. Small projects are those that earn us small money. The size of a project must be determined by how much value it creates for the 
company, rather than its scale. A small project can become a big one, and the same principle applies to our representative offices. We won't see heroes emerge in great numbers if our managers' personal grades are determined only by how large their scope of management is, how high the level of their department is, or how many functional units they manage. (Ren Zhengfei: Remarks at a Meeting with Members of the Project \& Financial Management Enablement Program for High Potentials, Huawei Executive Office Speech No. [2014] 054)

Our representative offices must be comprised of highly competent, lean teams, not large, cumbersome ones. This reflects our concept of "Squad Leaders' Fight". Where can these offices get the resources they lack? From mobile teams such as elite teams, the Key Project Department, and the Project Management Resource Pool. By utilizing mobile forces, we can downsize field command centers and manage them effectively to harvest more crops. (Ren Zhengfei: Speech at the EMT ST Meeting on July 25, 2014, Huawei Executive Office Speech No. [2014] 059)

The "Squad Leaders' Fight" is to make our operations flexible, agile, and efficient. At its core is the "mission command" approach, which, with the backing of the organization and systems, allows those who are closest to customers to call for support. By delegating authority and providing direction, mission command enables agile and adaptive lower-ranking commanders to carry out disciplined initiatives within the intents of their upper-level commanders. Mission command is the most effective way for lower-ranking commanders to realize the intents of their upper-level commanders. (Ren Zhengfei: Speech at a Briefing on the Takeaways and Challenges for Huawei Relating to the "Squad Leaders' Fight", Huawei Executive Office Speech No. [2014] 078)

Our entire organization needs to be restructured to make mission command effective. The "Squad Leaders' Fight" does not mean that we leave squad leaders to fight alone. Rather, this model requires the support of the following:

- Division of responsibilities: Give tactical command authority to field operating teams. Executives and HQ should focus on developing corporate strategies, setting the company's direction, and allocating resources.

- Authority delegation: Separate administrative management authority from operations command authority, and properly delegate authority based on clearly defined rules and the preparedness of subordinates. 
- Organizational structure: Remove or restructure field teams by function based on business needs.

- Resource distribution: Deploy tactical resources close to field operating teams and centrally allocate strategic resources to ensure rapid and effective response.

- Capability development: Comprehensively develop capabilities based on strategic needs.

- Processes: Business operations processes should focus on improving operating capabilities to adapt to a complex, volatile environment. Administrative management processes need to be rigorous and comprehensive.

- Information systems: Build an interconnected information environment to allow commanders at all levels to get whatever information they need anytime and anywhere to complete a task and develop a common understanding of the operating environment.

(Ren Zhengfei: Speech at a Briefing on the Takeaways and Challenges for Huawei Relating to the "Squad Leaders' Fight", Huawei Executive Office Speech No. [2014] 078)

Our representative offices act like fortresses for our company, so we must consider how we should build them in the future. Current US military theory talks about direct command to the battalion, not just to the brigade. Direct command to the battalion places this unit as the operational base, and the US military can do this because it has powerful longrange firepower and clear processes. However, Huawei's country-level business performance baselines are far from clear. Each country office should establish baselines based on its average business performance from the past three years. If business performance in a country exceeds its baseline, we can say the managers in this country have done a good job. Otherwise, managers in Shanghai will certainly be promoted faster than those in Mozambique or Malawi because these two countries have less potential contracts to secure. The same can be said for Iraq and Libya. In my opinion, the Human Resource Management Department's most important role is to manage rules. This includes appraisal rules for business performance baselines, which should be reviewed each year. If there is a war, epidemic, or other challenge in a region and you still expect staff there to meet the previous business performance baseline - the unified, global baseline - then I would consider your appraisal method rather backward. In China, how can Shanghai and Xinjiang be measured on the 
same scale? In turn, the China region must establish different business performance baselines according to the specific circumstances of each location. I worry that no one will want to go to work in less developed regions like Xinjiang and Latin America, and that our operations in these locations will collapse. Therefore, I've recently made trips to some of these regions. I've just been to Xinjiang, where I told our local staff that they must become the first in China to achieve the "Five Ones". Why did I say this? For each process, we have a process owner. If inventory accounts are inconsistent with actual goods, then you cannot pass certain process checkpoints, which will force you to ensure the CIAG. This way, within six months, five exemplary process owners will emerge - let's call them "generals-to-be" for the time being. The following year, these five generals-to-be will be moved to Urumqi to ensure the CIAG there. Five successors - or deputy process owners - will be chosen to look after their processes. These successors must not only maintain the CIAG along these processes, but also review the accounts of previous periods. By doing this, another five "generals-to-be" will emerge. The combined efforts of these two groups of "generals-to-be" will lead to the CIAG in Xinjiang, two to three years ahead of the China region. Xinjiang is positioned to achieve these results first and become a hotbed for "generals". When heroes and managers emerge from such difficult regions, other people will want to go to work there. If we do not use this type of approach, who will want to go to work in challenging regions? (Ren Zhengfei: Speech at a Briefing on the Takeaways and Challenges for Huawei Relating to the "Squad Leaders" Fight”, Huawei Executive Office Speech No. [2014] 078)

Representative offices should have the authority to select customers and products, and to make decisions on contracts. This will drive our back offices to transform. The decision-making authority of representative offices should be limited to businesses of uncertainty. Authority related to costs through the end-to-end process will not be delegated and these costs must follow pre-set baselines. (Ren Zhengfei: There Will Not Always Be Flowers Along the Road Abead-Speech at the HI Huawei Market Conference, Huawei Executive Office Speech No. [2016] 079)

Delegation of authority allows representative offices to approve more matters within a larger scope. Within our three-procedure loop, all business activities only need to go through three procedures - application, review, and approval. Achieving the three-procedure loop should be a goal that we pursue. This goal can only be attained if HQ can promptly provide the support and services that representative offices need to deliver results 
more easily and rapidly. (Source: Minutes of a Report on Delegation of Authority, Three-procedure Loop, and Contract Approval by Representative Offices, EMT Meeting Minutes No. [2016] 007)

All business domains are proactively delegating authority to field offices. The Executive Management Team (EMT) has approved three initiatives with regards to delegation, acquisition, and exercise of authority. First, regarding delegation of authority, we will review authority across processes in all domains, and delegate more authority to field offices from the top down. With a focus on field projects (known as the cells of business management), we must also holistically identify requests for authority from the bottom up while considering customer needs and business results, and then drive delegation of authority. Second, when it comes to acquisition of authority, our upper-level managers currently delegate authority on a level-by-level basis via delegation letters. Moving forward, authority will be directly assigned to field operating positions. Third, for exercise of authority, our existing processes cannot support diverse operating scenarios in the field, so we need to further clarify operating scenarios and optimize processes to ensure effective exercise of authority. (Source: Minutes of a Report on Delegation of Authority, Three-procedure Loop, and Contract Approval by Representative Offices, EMT Meeting Minutes No. [2016] 007)

Our appraisal policies need to vary by country, so that we can provide some support to hardship regions. Don't think that we just want to make money. After all, our mission is to serve humanity. We must take necessary measures to realize this mission. We might lose markets in some regions. That's okay. We must not allow them to drag our company down. (Ren Zhengfei: There Will Not Always Be Flowers Along the Road Abead-Speech at the HI Huawei Market Conference, Huawei Executive Office Speech No. [2016] 079)

\subsubsection{Using the Value Distribution System to Drive Business Units to Operate on Their Own, Responsible for Profits and Losses, and Incentives and Constraints}

Huawei has grown into what it is today because of its relatively balanced value distribution mechanism. Looking ahead, we must adopt diversified and multi-dimensional value distribution mechanisms. Support provided by different appraisal units must be reflected when we distribute value. We must ensure that the interests of all of our company stakeholders are 
balanced, and that all units across the company collaborate to achieve business success. We should also identify potential risks arising from delegation of the planning, budgeting, and accounting authority to business units, resolve the issue of value distribution across departments, and prevent the emergence of cliques with their own agendas. (Source: EMT Meeting Minutes No. [2008] 014)

We need to guide different business units through different performance indicator systems and appraisals. First, we need to examine market opportunities for the next two to three years, and identify which business units are becoming profit centers, which business units are in a transitional stage, and which business units are still in the growth stage. Second, we should fix the headcount and positions of business units that are built as profit centers. These business units will be appraised based on the profits they create for the company. When appraising business units that are built as sales centers, we should still focus on sales growth. Third, business units with a large revenue base and limited growth potential should be primarily appraised according to their absolute sales growth; business units with a small revenue base and large growth potential should primarily be appraised according to their relative sales growth. (Source: Minutes of the Report on the Q1 Business Review, EMT Meeting Minutes No. [2009] 031)

Our appraisal and incentive mechanisms are designed to encourage initiative. We need to gradually change from granting incentives from the top down to an approach that distributes value based on contribution. I expect to see a fundamental change in our appraisal and incentive mechanisms, moving from top-down value distribution, to performance-based value sharing. Once you have created value for the company, you can know roughly how much money you will get. This value sharing model will eliminate boss-centric behavior. In addition to sharing value with the company, you also need to share its risks, and accept the risk that you may earn less if you create less value for the company. Major risks faced by Huawei will be managed mainly through delegation of authority. (Ren Zhengfei: Speech at the Self-reflection Session of the Executive Committee of the Board of Directors, 2012)

Focusing on strategy and streamlining management are the key goals we must pursue. We need to delegate more authority and have fewer KPIs. We need to assess in-process work with fewer KPIs and eliminate KPIs intended for process segments. We need to gradually change our value distribution mechanism, from top-down granting to a Contribute and Share system. (Ren Zhengfei: Focusing on Strategy and Streamlining Management, Huawei Executive Office Speech No. [2012] 041) 
The objectives of management are to improve efficiency and harvest more crops. The most important KPI should always be whether a business has harvested more crops. This is to discourage everyone from managing just for the sake of managing, doing unnecessary things, and ignoring the importance of harvesting more crops. (Ren Zhengfei: Speech at the Report on the Integrated Management Transformation in Small Countries, Huawei Executive Office Speech No. [2014] 062)

\subsubsection{Leveraging the Value Sharing Mechanism and Strategic Investment to Reinforce Our Culture of "Toasting Those Who Succeed and Offering a Helping Hand to Those Who Fail”}

We must encourage collective dedication. Our appraisal and incentive mechanisms should support both our customer-centric culture and our fine tradition of "toasting those who succeed and offering a helping hand to those who fail." Our incentive mechanisms, such as adjusted statistics and adjusted performance appraisals, will ensure that value is shared between field and back offices, and between operating and supporting teams. (Source: EMT Meeting Minutes No. [2008] 021)

To seize strategic opportunities, we may need to sacrifice some of the interests of shareholders temporarily and allow for a decline in our profits. We must first make our compensation structure more reasonable and formulate reasonable HR policies. During our pursuit of strategic opportunities, we may end up losing opportunities if we control compensation too tightly in order to maintain profits. (Ren Zhengfei: Guidelines on the Analysis of the Business Environment and Key Business Strategies, Corp. Doc. No. [2012] 081)

The Regions Management Department should review the appraisal baselines for countries with strict foreign exchange controls every year. We need to provide more timely incentives to teams in these countries so they will be motivated to make significant contributions. For these countries, we have always stressed that we sign contracts based on the amount of cash that can be repatriated to China. If the amount that can be repatriated in a given country is low, we need to reduce headcount there and transfer some employees elsewhere to seize strategic opportunities. When it comes to trapped cash, managers at all levels should study Huawei Executive Office Speech No. [2014] 071 Remarks by Ren Zhengfei During Visits to Countries Where Cash Is Trapped. In that speech, I gave clear instructions on how to deal with trapped cash. In the future, HQ will develop techniques for strategic decisions and function as an experts' team 
to make decisions on trapped cash issues. Project decision-making authority will be delegated to representative offices, regional offices, and subsidiary boards. This way, subsidiary boards will have both authority and responsibility, and authority will be moved closer to field offices. (Ren Zhengfei: Minutes of the Briefing on the Progress of Differentiated Appraisals for Regions, Huawei Executive Office Speech No. [2015] 050)

In countries affected by war, civil unrest, or epidemics, HQ can bear certain costs. This includes the cost of bottled water and dried food in desert areas, or face masks in polluted countries. Can HQ bear satellite rental costs to ensure Internet access in war-torn countries? Without network access, people cannot work. Remember, our employees are paid high wages. If such costs are paid by HQ, we would be able to develop reasonable appraisal baselines for different regions around the world. (Ren Zhengfei: Minutes of the Briefing on the Progress of Differentiated Appraisals for Regions, Huawei Executive Office Speech No. [2015] 050)

"Toasting those who succeed and offering a helping hand to those who fail." This is a slogan we coined in our early years, and it represented exactly what we did at work. But we have stopped following the spirit of this slogan. Why is that? It is because of our KPI-based appraisal system. When every representative office has their own sources of interests, they tend to work in isolation and hoard resources without considering the overall interests of the company. We need to revert to our original model that prioritizes the interests of the company as a whole. There needs to be major changes to our KPI-based appraisal system. Change is taking place gradually. Failure will be inevitable if field offices prioritize their own interests to the exclusion of all else. Through continuous improvement, we need to get rid of that mentality and adopt new work approaches. I see three operating scenarios for the future. First, there will be representative offices that are able to operate independently, without the support of our elite teams. Second, there will be representative offices that need the support of elite teams. They must pay for these elite team resources, and the company encourages them to seek support by giving them a budget for this purpose. When an elite team has helped a representative office secure a project, the costs of that elite team must be accounted for under the representative office. The costs must be recovered, because once the project is won, the representative office will have access to more opportunities. If the project fails, the company will bear the costs. In the third scenario, when there are huge changes in a hardship region, the local representative office can directly transfer its employees to the three elite teams of the 
Strategic Reserve where they can rotate and receive training. True quality shines through, no matter where an employee works, be it the elite teams, the Key Project Department, or the Project Management Resource Pool. (Ren Zhengfei: Speech at a Meeting with Trainees at the First Training Session for the Global Solutions Elite Team, Huawei Executive Office Speech No. [2014] 064)

\subsection{Methods for Managing Responsibility Centers}

\subsubsection{We Establish Responsibility Centers to Define Responsibilities, Streamline Management, and Motivate the Workforce}

Just now, you said you wanted to adapt our processes to all three business groups (BGs). Then, what is the point of dividing our business into three BGs? At a previous briefing on financial budgeting, the presenter began the session by talking about adapting processes to support multi-BG expansion. I simply asked the presenter to stop talking and leave. Who says we will need multi-BG expansion? Our three-BG structure aims to streamline management, with each BG operating independently from each other. There is no need to adapt our processes to all three BGs. Resource sharing was important when the company was small, but this approach causes waste when the company is large. We have made our processes all-encompassing and excessively large, due to our overemphasis on process adaptation. When major processes are clean and transparent, we can streamline major sub-processes. After all unnecessary functions are removed, our sub-processes will become open and flexible. (Ren Zhengfei: Speech and Comments at the Strategy Retreat of the Business Process \& IT Management Department, Huawei Executive Office Speech No. [2012] 026)

To reduce airfare costs, representative offices used to hire many people. This made it difficult for them to adapt to changes in business volume. Now, we have implemented a compensation package system, which has led to some changes. However, headcount in representative offices is still too high. Strategic mobile forces should be used to adjust this structure. (Ren Zhengfei: Speech at a Briefing on the Takeaways and Challenges for Huawei Relating to the "Squad Leaders' Fight", Huawei Executive Office Speech No. [2014] 078) 
The purpose of transformation is to make operations easier, more prompt, and more accurate. (Ren Zhengfei: The Purpose of Transformation Is to Make Operations Easier, More Prompt, and More Accurate-Speech at the Briefing on the ISC+ Transformation Program, Huawei Executive Office Speech No. [2016] 016)

The goal of management is to effectively generate revenue. We must first streamline sales processes and then delivery processes, including our supply chain, allowing them to operate with agility. We should never accept processes that are not streamlined with the excuse that we are optimizing them. We must not invest huge amounts of resources in approving contracts level by level just to avoid shipping the wrong board. I would rather see such a mistake happen. We can analyze root causes later, but we need to streamline processes first. (Ren Zhengfei: There Will Not Always Be Flowers Along the Road Abead-Speech at the HI Huawei Market Conference, Huawei Executive Office Speech No. [2016] 079)

The purpose of management is to help the company succeed. We need to assign both responsibility and authority to managers at every control point of our processes, with appropriate oversight in place, of course. Many approvers sign their names without even looking at what they are signing. So why do we need such a control point? It's not necessary at all. We will gradually optimize our customer service process along two key lines. One is sales and the other is delivery. We must resolve customer problems quickly. We will also optimize our internal service processes, for example, finance. However, this optimization must not impact the sales process. (Ren Zhengfei: There Will Not Always Be Flowers Along the Road Ahead-Speech at the HI Huawei Market Conference, Huawei Executive Office Speech No. [2016] 079)

The objectives and responsibilities of our managers at all levels must be clearly defined. Our appraisal system focuses on responsibilities and results. This system has created a simple and positive climate at Huawei, allowing more employees to fix their eyes on customers. Our focus on responsibilities and results will nurture many outstanding managers and discourage ingratiation and flattery at Huawei. (Ren Zhengfei: Firm Belief and Strong Focus Lead to Greater Success-Speech at the 2016 Huawei Market Conference, Huawei Executive Office Speech No. [2016] 007)

The Logistics Service Department should have the ability to provide professional services. The department should establish basic rules, and learn how to effectively leverage supplier resources to make up for its lack of capabilities. We should concentrate our supplier resources by reducing 
the number of suppliers, identifying suppliers that deliver high quality, and paying higher prices for their high-quality services. (Ren Zhengfei: Speech on the Work of the Logistics Service Department and Smartcom, Huawei Executive Office Speech No. [2016] 086)

Smartcom should try its best to outsource fragmented businesses, as this will streamline management and make it possible to provide highquality, differentiated services. You might encounter problems early on in this process, but don't step back. You must be resolute. You should gradually outsource these businesses. If you open up to the outside world, your management abilities will mature and you will make our campus increasingly prosperous. When people make money, they become greatly motivated. Smartcom should only run a small part of businesses that are not yet ready for outsourcing. Outlets run by Smartcom should be appraised according to market rules. Don't turn Smartcom into a "groupowned company". You should establish a competition mechanism. The Employee Service Department is not the International Conference Center, so cost accounting needs to be performed. All costs for self-run outlets should be calculated, including rent, water, electricity bills, compensation, and dividends. All should be included in the virtual financial statement, which will be monitored and managed so that your business will continuously improve. (Ren Zhengfei: Speech on the Work of the Logistics Service Department and Smartcom, Huawei Executive Office Speech No. [2016] 086)

PO generation needs to be shifted forward. We must strive to generate POs correctly on the first try. If complaints about PO errors are filed after shipment, the back office should promptly review the rules that allowed the errors and make adjustments. They should not just examine and approve each PO. We will reduce the examination process from four steps to two. The first step should be easy, so people can do things right. During the second step, people with field experience should take charge of the examination, as they know where the errors are, and how to find and rectify them. Rules should only be changed after repeated reasoning. We should strive to reduce the original four levels of responsibility to two. The first level takes ultimate responsibility for the POs, whereas the second level takes responsibility for process rectification. (Ren Zhengfei: Speech at the EMT ST Meeting on January 25, 2016, Huawei Executive Office Speech No. [2016] 054)

Project-centered organizations and representative offices are the focuses of our organization transformation that involves our regional carrier and 
enterprise businesses. The aim of this transformation is to improve the decision-making capabilities of our field offices. We will give them responsibility, authority, and the corresponding interests. We will pilot a model where representative offices have the authority to approve contracts. The focus of our transformation over the next several years is to allow representative offices to make decisions on business operations, BGs to coordinate resources and develop capabilities, and HQ to provide service and support. We will use projects to guide representative offices, and use representative offices to guide Greater Regions and regional offices. Delegating authority is a means to an end. We also need to strengthen systematic training and oversight. We need to improve the decision-making capabilities of field offices, because making decisions is also fulfilling responsibilities. Moving forward, regional offices will have several layers of operational responsibility centers. The first layer will be project-centered organizations. The second layer will be key account departments of representative offices. The third layer will be representative offices. The company's Board of Directors assumes the ultimate responsibility for business operations, and HQ provides service and support to help fulfill this responsibility. Revolving around these layers of operational responsibility centers, we need to define responsibility, and design authority, oversight, and manager appraisal criteria. Greater Regions and regional offices above representative offices will not necessarily become operational responsibility centers. (Ren Zhengfei: Speech at a Briefing on Improvements and Future Planning for Carrier and Enterprise Regional Organization Transformation, Huawei Executive Office Speech No. [2017] 030)

\subsubsection{Incorporating Checks and Balances into Responsibility Center Management}

Over the years, the business relationship between BGs and regional offices has been unclear. Yesterday, the relationship was finally clarified. Regional offices are command centers that have the authority to command operations, select products, and make decisions on contracts. BGs provide necessary resources and collaborate with regional offices to secure contracts. The Joint Committee of Regions (JCR) will mainly drive the establishment of a manager rotation mechanism and create a favorable work environment. Its biggest decision-making authority relates to manager deployment, not business decisions. The JCR can't directly manage projects. The JCR, BGs, and regional offices need to work closely together 
towards the same goal and achieve business success. They should not operate independently from one another. Some people may ask, "Can BGs rotate their managers?" Yes, they can, but they should primarily rotate managers within their BGs. Cross-domain rotation may not be possible for them. The JCR can rotate outstanding managers across domains in different departments after conducting joint reviews. (Ren Zhengfei: Speech at a Meeting with Trainees at the First Training Session for the Sales Project Management Resource Pool, Huawei Executive Office Speech No. [2014] 066)

During organizational transformation, the ultimate command or decision-making authority needs to be clearly delegated. We first need to be clear about which types of authority should be delegated to regional offices, and which to BGs. I agree that there can be many different types of decision-making authority, but what I mean here is the "ultimate" decision-making authority. BGs are sales-revenue-oriented, while regional offices are profit-oriented. I believe that business decision-making authority should be given to regional offices. BGs should focus their efforts on building up resources, developing strategies, and taking part in operations. In order to increase sales revenue, BGs should find ways to persuade field commanders to adopt their points of view. I tend to agree that the Consumer BG holds the decision-making authority over its own business. For all other businesses, however, decision-making authority rests with regional offices. (Ren Zhengfei: Speech at a Briefing on the Takeaways and Challenges for Huawei Relating to the "Squad Leaders' Fight", Huawei Executive Office Speech No. [2014] 078)

To reduce airfare costs, representative offices used to hire many people. This made it difficult for them to adapt to changes in business volume. Now, we have implemented a compensation package system, which has led to some changes. However, headcount in representative offices is still too high. Strategic mobile forces should be used to adjust this structure. (Ren Zhengfei: Speech at a Briefing on the Takeaways and Challenges for Huawei Relating to the "Squad Leaders' Fight", Huawei Executive Office Speech No. [2014] 078)

When giving the ultimate decision-making authority to field commanders, it is important that we do not allow BGs or the Strategic Reserve to do what field commanders are supposed to do. If you do not think field commanders are up to the job, you can redeploy them and appoint new ones. However, the command authority should still remain with the field. We can take our recent meeting about how to address strict foreign 
exchange controls in Latin America as an example. The first point I would like to make in this respect is that the countries and personnel who are involved in addressing funds repatriation difficulties are the main operating teams. These people should be put ahead of even our sales teams in terms of opportunities to move higher up in the ranks, including manager selection. The reason is if they can find a way to repatriate 80 million dollars of foreign exchange, then achieving 80 million dollars in sales for that area will be a piece of cake. Despite this, we have treated these employees as low-ranking "aides" for too long. How does this help us solve our problems? Second, I think we should delegate the decision-making authority on operational matters to subsidiary boards of directors. In the past, approval was made by HQ. But HQ cannot handle all approval requests. What kind of decision-making authority should HQ have? Decisions on solutions. Our experts have decision-making authority over solutions. When it comes to execution, however, the decision-making authority should rest with the field. Regarding the oversight over decisions made in the field, subsidiary boards of directors have a role to play. I mention this point in the hopes that the Treasury Solution Department and the Finance Planning Department will step up to solve this problem. (Ren Zhengfei: Speech at a Briefing on the Takeaways and Challenges for Huawei Relating to the "Squad Leaders' Fight", Huawei Executive Office Speech No. [2014] 078)

We need to consolidate departments and reduce the review levels more rapidly, giving field offices the authority to approve more matters. Don't panic about authority delegation. We will still run audits on any exercise of authority. Representative offices will become profit centers and have certain command authority. As we continue to delegate more authority, representative office operating platforms will become larger for a period of time. This is because the shift of our HQ management platform forward to field offices is a process of gradual transformation. (Ren Zhengfei: The Purpose of Transformation Is to Make Operations Easier, More Prompt, and More Accurate-Speech at the Briefing on the ISC+ Transformation Program, Huawei Executive Office Speech No. [2016] 016)

There must be checks and balances between regional offices and BGs in terms of planning systems. BGs should have more ambitious sales plans, while regional offices should remain a little more conservative. You asked earlier about "deploying troops" and "maintaining troops", the projectbased operations of marketing execution teams (METs). First, we need to 
change from unified planning to a more diversified approach to planning. This is something we've learned from the US military. US command centers have the authority to make battle decisions, but have no troops of their own. In contrast, its resource centers have troops, but don't have the authority to make battle decisions. Our BGs and product lines are our resource centers. They can see more opportunities, so their sales plans should be more ambitious. They should actively market their own products, and do not have to worry too much about project profits. Our regional offices are profit centers. Their sales plans should be more conservative, because they have to avoid locking themselves into situations that will bleed away their investment. Between the ambitious and the conservative, we have found a balance. Looking back at the system now, we see that it has helped boost the quality of our product lines even if it took time for us to understand the details. If BGs' sales plan targets are lower than regions', the BGs need to go back and rethink their plans. (Ren Zhengfei: Building the Carrier BG's "Three-Cloud" Platform to Equip Field Offices with the Best Tools-Speech at the Carrier BG's Briefing on Developing Marketing Tools, Huawei Executive Office Speech No. [2015] 019)

Regional offices have command authority and project decision-making authority, while BGs act as resource centers to support field operations. The goal of BGs is to increase sales while the goal of regional offices is to generate decent profits. Over the next five to ten years, regional offices will gradually change their function from maintaining large troops to building lean teams. If manpower is insufficient, the Strategic Reserve will act as a mobile force to provide support. In the future, our field offices will be made up of lean teams that deal with uncertainties, and our back offices will be made up of shared platforms that deal with certainties. This allows those closest to customers to call for support, and as a result, our overall operating capabilities will improve. In the future, the company's authority system will become a two-pole system. One pole will be regional offices. They are close to customers, and will command field operations. The other pole will be BGs. They will have the authority to provide support and services. BGs will focus on sales revenue, and regional offices on profits. That way, there will be checks and balances between the two poles. (Ren Zhengfei: Speech at the Oath-taking and Awards Ceremony of the Transformation Elite Team, Huawei Executive Office Speech No. [2015] 047)

Our incremental markets need to include countries with big opportunities. Small countries and hardship countries should be appraised against 
reasonable market share and reasonable profits. The "red dancing shoes" of sales revenue should be avoided. Having a high market share might not be a good thing. In some countries, we have landed contracts with local top three telecom carriers. Because the marketplace is often a zero-sum game, some of these carriers may collapse in the face of fierce competition. If you try to play the hero and rush in to save the day by cutting prices for the third-place carrier, you might end up dragging down the prices of the top two carriers as well. (Ren Zhengfei: Our Human Resource Policy Should Develop in the Direction of Decreasing Entropy-Speech at a Report of the Strategic Reserve to Its Steering Committee, Huawei Executive Office Speech No. [2016] 098)

We have established an accountability mechanism that promotes collaboration between different teams, allowing Sales to hold R\&D accountable, R\&D to be responsible for customers, and Marketing to serve as a bridge between Sales and R\&D. Contributions to revenue should be included in the appraisal of product lines, so that they will be forced to deliver products and services that are needed by representative offices. Product R\&D, Technical Sales, and Services must collaborate to develop solutions. Field personnel must not make commitments rashly, and must confine their commitments to the list of sellable products. New customer requirements must be discussed with Marketing, and product development can only begin after a resolution is reached. (Ren Zhengfei: There Will Not Always Be Flowers Along the Road Abead-Speech at the HI Huawei Market Conference, Huawei Executive Office Speech No. [2016] 079)

How can R\&D ensure that they are customer-centric? R\&D should organize meetings to develop appropriate measures. Marketing must serve as a bridge between Sales and R\&D, and must dare to speak the truth. If no one intervenes in product line $\mathrm{R} \& \mathrm{D}$, will the products they independently develop meet customer needs? Will these products be competitive? We stress that representative offices are profit-centered and product lines are revenue-centered. Representative offices have the authority to select which customers they serve, which products they sell, and which sales contracts they sign. Product lines must reach out to Technical Sales, Production, and Services. This will force our R\&D to become customer-centric. Without sales revenue, life will be difficult for them. (Ren Zhengfei: There Will Not Always Be Flowers Along the Road Ahead-Speech at the HI Huawei Market Conference, Huawei Executive Office Speech No. [2016] 079) 
Expenses in small countries are high, so we must ensure that the expenses claimed in these countries are real. We don't worry too much about whether they are reasonable. We then compare real expenses with the profits these countries earn. Today network quality in small countries is not very good. Why? Employees in these countries are unable to obtain the resources needed to improve. There are very few base stations in small countries, and they don't have much money, so it is difficult for them to obtain the required resources. If they had the money to buy more resources, no one would hesitate to join them. Therefore, small countries need to have reasonable profits and a reasonable market share. As long as expenses in small countries are fact-based and free from corruption, they are understandable. Neither big countries nor small countries are allowed to falsify data. (Ren Zhengfei: Internal and External Compliance to Generate More Revenue and Pave the Way for the Company's Future Success-Speech at a Meeting with the Oversight Team, Huawei Executive Office Speech No. [2017] 002)

\subsubsection{Responsibility Centers Must Adopt Different Approaches to Manage Certainties and Uncertainties}

At the moment, some certainties are still managed as uncertainties, resulting in too much discussion, low efficiency, and wasted energy, and leaving too little time to deal with true uncertainties. Due to historical factors, HQ is filled with managers. In the future, we aim to equip HQ with a team of outstanding experts who are able to handle everything from Big Video, massive data traffic, big frameworks, and broad services to estimation and final accounting, system delivery, integrated maintenance, and transaction management. When field offices have a demand, these experts can provide support immediately. Every three to five years, these experts must rotate to the field to work on or run projects. We will also develop local experts' teams based on customer needs. (Ren Zhengfei: Speech at the Report on How to Develop Contract Scenario Experts, Huawei Executive Office Speech No. [2015] 071)

When I met with the Chairman of Accenture recently, I told him that Huawei had worked with IBM for over 20 years and had turned our fragmented processes and systems into a shared platform. Over the next 10 years, we will work with Accenture to change our organization from one of large teams into one of lean teams. We will deploy lean teams that 
deal with the uncertainties of transaction terms, customer needs, new technologies, and scenario management. The shared platform will deal with issues of certainty. In this way, we can reduce headcount while hitting the same sales targets. The increased profits can be distributed to these lean teams to boost their operating capabilities. This means that when we set different baselines for different countries and different industries, we are in fact stepping closer to building lean teams. (Ren Zhengfei: Minutes of the Briefing on the Progress of Differentiated Appraisals for Regions, Huawei Executive Office Speech No. [2015] 050)

At Huawei, if you want a high salary, you have to earn it. Those who put the most food on the table become our "generals". Generals are born of battle. So everyone must keep up the hard work, and keep making solid improvements in their ability to do their job. Delivery managers deal with certainties, so they should first increase efficiency and effectiveness. Service managers deal with uncertainties, so they should build up their overall ability to quickly deal with technical problems. Looking ahead, these two categories of managers should each be responsible for their own development. We should apply different performance appraisal criteria to these two categories. (Ren Zhengfei: Generals Are Born of Battle-Speech at the 2015 Project Management Summit, Huawei Executive Office Speech No. [2015] 118)

Commanders should focus on strategic goals and success, and deal with uncertainties. Daily matters of certainty should be handled by the General Manager's Office and the Quality Operations Department. The appraisal of matters of certainty should focus on the efficiency and quality of management, and process compliance is the best management approach for such matters. Of course, we can optimize our processes following specific procedures. There is much work of uncertainty in representative offices, so we are authorizing general managers to handle such work and asking them to be profit-centered. This means that representative offices have the authority to select which customers they serve, which products they sell, and which sales contracts they sign. The decision-making authority is not delegated based on the costs of the end-to-end process, but on the costs incurred by uncertainties. At the end of each year, we need to calculate how much profit each representative office earns. Their total profits will determine their performance rating and the amount of money they can distribute. (Ren Zhengfei: Speech at a Meeting with Employees of the Central Asia of Caucasia Region, Huawei Executive Office Speech No. [2016] 063) 


\subsection{Operating Mechanisms for Profit Centers}

\subsubsection{Focusing on Business Operations, Making Decisions Independently, and Never Rigidly Setting Job Grades Based on Scale and Levels}

We must gradually change HQ from a management and control center to a support and service center that also performs oversight functions. We need to develop capabilities that enable the field to drive back offices. We need to plan and make a shift from centralized management and control to delegation of operations authority to entry-level operating teams, ensuring our command centers are as close to our customers as possible. We need to help organizations at all levels become profit centers that reflect their own business characteristics. (Source: Resolution on the EMT's Priorities and Management Approaches from 2007 to 2009, EMT Resolution No. [2007] 012)

The company is now focused on developing profit-centric organizations. HQ must provide services to profit centers. In the future, profit centers will view project profits as a key factor in their decisions. Project managers must be project-centric and ensure profits. (Ren Zhengfei: Remarks at a Meeting with Senior Managers at a Project Management Summit, Huawei Executive Office Speech No. [2009] 007)

As various transformations are implemented across the company over the next five to ten years, our representative offices will shift from maintaining large teams to building lean teams. Today, we have thousands of people in one representative office. Why do we need to maintain all these troops? If there is a sudden drop in a representative office's business, the office will not be able to feed them all. Representative offices are integrated units that are directly engaged in field operations. When a representative office selects the smallest possible team to engage in battle, that is a lean team. A representative office is commanded by its general manager, who has the ultimate authority over the entire office. If a representative office has multiple managers, there will be chaos and no battles can be fought. If there aren't enough personnel in representative offices, we can transfer some in from our strategic mobile forces. This is how we make our personnel mobile. Once we shift to open source code and open platforms, we can reduce duplicated development, and our R\&D team will also become smaller. This is no longer a time in which we position ourselves by how many people we manage, how big our team is, or what level we are 
at. In the past, one could become a "platoon leader" only when he/she commanded dozens of people. Today, you can become a team leader, or even a "major general", with just three subordinates. As our organization gradually slims down, how are we going to deploy so many leaders? We need to change our approach. In battle, leaders still need to take on some of the work alongside their subordinates. Don't say that we cannot deploy a senior expert in a small team. We must have mechanisms to ensure that small teams can have senior experts, so that everyone can have confidence. Huawei's management system still needs to be improved. We can't rigidly set job grades based on job assessment results. Managers might have low job grades, but they should not have to worry about it - they still have the opportunity to become generals. Experts may be petty officers, but they can also enjoy special treatment. That's what creates the Huawei "can-do" spirit. In the US Department of Defense, a petty officer can effectively command a brigadier because he is in charge of global oil supplies. Often, what we need is an expert, not necessarily a general. That is something we need to consider during our management transformation. If we rigidly set job grades based on job assessment results, we will end up with no room for veteran experts, and our experts may choose to leave. (Ren Zhengfei: Building the Carrier BG's "Three-Cloud" Platform to Equip Field Offices with the Best Tools-Speech at the Carrier BG's Briefing on Developing Marketing Tools, Huawei Executive Office Speech No. [2015] 019)

We must allow those who are closest to our customers to call for support. This gives field offices the freedom to make decisions according to actual circumstances. Finance can then impose constraints based on how many resources were invested and how much revenue was generated. Our audit department will verify the facts and check where the resources have been deployed. If field offices don't generate any revenue, they will receive nothing according to our Contribute and Share system. This will be decided by our Human Resource Management Department and Corporate Leadership Management Department. As we link all costs, we will form a scientific operating model over the next few years. We will then transfer operating authority to field offices, and move our oversight teams forward by establishing subsidiary boards of directors. Together, all this will move field offices closer to our customers and increase our scope of engagement. Meanwhile, we will have the support of the Carrier BG as a center of expertise $(\mathrm{COE})$ and a resource center. This will open the market to us. Therefore, I think regional offices should act as command centers and call for support. While they don't have operating teams, they do have operating 
authority. The Carrier BG should serve as a COE, a resource center, and a customer solution design center. The Carrier BG has operating teams but no operating authority. To deploy operating teams, you will need to receive approval from field command centers. Otherwise, you won't get a budget. We will spend ten years developing an operating system according to this concept. (Ren Zhengfei: Building Advanced Tools and Enhancing Core Competencies to Achieve Success at a Higher Level-Speech at a Carrier $B G$ Briefing on the Service Experience and Phased Acceptance of the "Three Cloud" Platform, Huawei Executive Office Speech No. [2015] 099)

You have to allow those who are closest to our customers to call for support. That is how the US military operates, and we should learn from them, because the US military is the worlds' most powerful organization. The US is a country that values freedom, but the US military is extremely disciplined and is always improving itself. In that respect, it is exactly the same as Huawei. The Carrier BG currently advocates the "Three Cloud" strategy. This is actually its President's way of shaking up his organization and delegating authority to the field. In the future, this BG will be a resource center and a center of expertise. Our back office will become a team of elite experts who provide support to our field offices. Recently, President of the Regions Management Department was telling me that the department is also becoming a "commercial management cloud". This is what they are calling their experts' teams that mainly work on commercial management issues. These teams will enable us to speed up the delegation of authority to the field. So, where should we delegate authority first? Small countries. (Ren Zhengfei: Building Lean Teams in Small Countries First; Allowing Field Teams to Call for Support-Speech at the Report of the JCR's Regions Management Department on Approaches to Small Country Operations, Huawei Executive Office Speech No. [2015] 126)

\subsubsection{Positioning HQ as a Resource Pool and Adopting a Resource Buy \& Sell Mechanism}

Delegating command authority to the field prevents HQ from becoming too bloated. If HQ keeps all command authority to itself, it will not generate new value despite the fact the organization will keep expanding and operating costs will continue to rise. Sooner or later, the company would collapse. We can see this happening throughout history with the decline of both big corporations and feudal dynasties. At this critical moment in our own history, we must be fully aware of the risks of an overly large HQ, and 
thus further delegate authority to field offices. We must streamline our Lead to Cash (LTC) process to achieve our CIAG and "Five Ones". Our subsidiary boards are taking on a historic mission during this period of transition. (Ren Zhengfei: Speech at the Mid-year Workshop on the Enablement of Subsidiary Board Directors, Huawei Executive Office Speech No. [2014] 074)

We will position our HQ as a resource pool and adopt a resource "buy \& sell" mechanism, through which field offices can request resources and back offices can provide resources based on project budgets while also charging fees for the resources they provide. This mechanism will mean that those with money will have command authority, and approval by managers at HQ will no longer be required. This way, we can achieve checks and balances between field and back offices to ensure that field offices don't become aimless and back offices have clearly defined capability requirements. (Ren Zhengfei: Speech at a Carrier BG Briefing on the Progress of Three Cloud 2.0, Huawei Executive Office Speech No. [2017] 018)

Regional organization transformation aims to turn regional offices into COEs and resource centers. HQ is a resource pool, and resources must be bought and sold according to market rules. In addition, regional offices should guide the company's functional departments, R\&D, and BGs. When field offices need to purchase resources, we will set prices using the Cost, Insurance, and Freight (CIF) model. We are now piloting this model. The company's fixed costs are added into the CIF-based prices, and we thus have globally standard prices prior to local customs clearance. Representative offices will be given the authority to make pricing decisions involving uncertain factors. Any additional profits obtained through CIF pricing will not be placed under HQ. After deducting the average salaries and bonuses that are allowed by HQ, these profits will be shared globally among all employees via a secondary profit distribution mechanism. The building of regional COEs and resource centers is not confined strictly to Greater Regions; regional offices can also be part of these efforts. The company's Board of Directors assumes the ultimate responsibility for business operations and ensures that COEs improve their capabilities and resource centers provide more support. (Ren Zhengfei: Speech at a Briefing on Improvements and Future Planning for Carrier and Enterprise Regional Organization Transformation, Huawei Executive Office Speech No. [2017] 030) 


\subsubsection{Authority Delegation and Responsibility for Profit Centers}

Representative office general managers should be competent at running organizations, turning representative offices into profit centers, and taking responsibility for sustainable and profitable growth. (Ren Zhengfei: Staying Customer-centric, Inspiring Dedication, and Persevering Are Key to Our Success-Speech at the 2010 Huawei Market Conference, Huawei Executive Office Speech No. [2010] 002)

In the "Squad Leaders' Fight", the ultimate command and decisionmaking authority should be with regional offices. BGs and the Strategic Reserve are resource centers and mobile forces respectively, both of which provide operational assistance. (Ren Zhengfei: Speech at a Briefing on the Takeaways and Challenges for Huawei Relating to the "Squad Leaders' Fight", Huawei Executive Office Speech No. [2014] 078)

What does command authority mean? It is the actual ability to orchestrate capabilities. When it comes to authority delegation, we will give field offices the authority to select which customers they serve, which products they sell, and which sales contracts they sign. We will delegate authority to field offices, letting field commanders decide what capabilities they need and how to apply those capabilities to the opportunities they see. This way, field offices that are good at capability orchestration will make more money. If field offices don't know how to coordinate and utilize capabilities, our BGs can assign an experts' team to guide them to develop an operating solution. However, the experts' team should not interfere with business operations, and the decision-making authority still rests with field offices. (Ren Zhengfei: Speech at a Carrier BG Briefing on the Progress of Three Cloud 2.0, Huawei Executive Office Speech No. [2017] 018)

The military is made up of brigades, battalions, and companies. We will model our company on this structure and divide our departments into three types of units: brigades (large regional offices, resource centers, and HQ, which will sell resources to field offices), battalions (the operating platforms of representative offices), and companies (key account departments and project management centers of representative offices). We also need to use modern tools to reduce the number of layers in our management and improve the operating and decision-making capabilities of field offices. HQ will retain authority over treasury, accounting, and auditing and internal controls while delegating other authority to field offices. As long as data is transparent, the business decision-making authority will be 
delegated to field teams. As a result, these teams will have authority, responsibility, and interests, and will exert controls on themselves. (Ren Zhengfei: Speech at a Meeting in Paraguay, Huawei Executive Office Speech No. [2017] 025)

Our transformation should begin with projects and gradually progress into key account departments and representative offices. We will pilot delegating authority, and granting responsibility and interests to representative offices. Right now, some projects are recording huge waste of raw materials. This problem will be solved when interests are linked to representative offices, because they will proactively think about how to optimize their projects. In the future, representative offices will become profit centers. Key account departments will become coordinators and will have some decision-making authority. After the adoption of the CIF model, our product prices before local customs fees and expenses are added will be the same for all representative offices globally. However, costs related to customs clearance, engineering, and delivery are uncertain, because they differ by country. This means final sales prices will be different, and key account departments must not interfere with these final delivery prices. Assigning responsibility, authority, and interests to representative offices is a way to ask them to make decisions on local uncertainties. A price reference table for auxiliary materials will be released by our Procurement, and representative offices can choose whether to procure those materials from HQ or to procure them locally. Of course, allowing representative offices to approve contracts means we are giving them the leeway to also make mistakes (decisions that result in loss-bearing projects). However, they must assume responsibility for these mistakes and the losses must be made up in other projects. Subsidiary boards will oversee the internal and external compliance of representative offices, but will not interfere with their operations. Representative offices can be authorized to balance things out themselves. If we demand that everything must grow in value, we will only paralyze our workforce. (Ren Zhengfei: Speech at a Briefing on Improvements and Future Planning for Carrier and Enterprise Regional Organization Transformation, Huawei Executive Office Speech No. [2017] 030) 
Open Access This chapter is licensed under the terms of the Creative Commons Attribution-NonCommercial-NoDerivatives 4.0 International License (http:// creativecommons.org/licenses/by-nc-nd/4.0/), which permits any noncommercial use, sharing, distribution and reproduction in any medium or format, as long as you give appropriate credit to the original author(s) and the source, provide a link to the Creative Commons licence and indicate if you modified the licensed material. You do not have permission under this license to share adapted material derived from this chapter or parts of it.

The images or other third party material in this chapter are included in the chapter's Creative Commons licence, unless indicated otherwise in a credit line to the material. If material is not included in the chapter's Creative Commons licence and your intended use is not permitted by statutory regulation or exceeds the permitted use, you will need to obtain permission directly from the copyright holder. 